\title{
Harvesting period of jabuticaba fruits var. 'Pingo de Mel' in relation to the physicochemical characterization evaluated during their development
}

\author{
Lismaíra Gonçalves Caixeta Garcia1, Flávio Alves da Silva1*, Eduardo Ramirez Asquieri², \\ Eduardo Valério de Barros Vilas Boas ${ }^{3}$, Monik Marielly Moreira Silva ${ }^{4}$, Clarissa Damiani ${ }^{4}$ \\ ${ }^{1}$ Agronomy Department, Federal University of Goiás - Samambaia Campus, Box 131, CEP 74690-900, Goiânia, Goiás, Brazil, ${ }^{2}$ Pharmacy \\ Department, Federal University of Goiás - Colemar Natal e Silva Campus, CEP 74605-190, Goiânia, Goiás, Brazil, ${ }^{3}$ Food Science \\ Department, Federal University of Lavras - Universitário Campus, Box 37, CEP 37200-000, Lavras, Minas Gerias, Brazil, ${ }^{4}$ Food Technology \\ Department, Federal University of Goiás - Samambaia Campus, Box 131, CEP 74690-900, Goiânia, Goiás, Brazil
}

\section{A B S TR A C T}

\begin{abstract}
The objective was to physically and chemically characterize jabuticaba fruits var. 'Pingo de Mel' during their development. Some fruits were harvested ten days after flowering (DAF) and harvesting was continued at four day intervals until the fruits were completely ripe (34 days). It was shown that the values for the diameter, mass, soluble solids and anthocyanins increased up to $30 \mathrm{DAF}$, whereas the soluble pectin content and ratio (relationship between soluble solids content and titratable acidity) increased up to 34 DAF. The respiratory rate showed the opposite behavior, reducing up to $30 \mathrm{DAF}$, and the values for firmness and chlorophyll reduced up to $34 \mathrm{DAF}$. The pH and ratio reduced up to $18 \mathrm{DAF}$ with a subsequent increase up to $34 \mathrm{DAF}$, whereas the acidity showed the opposite behavior. In order to obtain high quality fruits with respect to ripeness it is important to consider the soluble solids and anthocyanin contents, which the present study showed to be indicators of the best moment for harvesting, that is, 30 DAF.
\end{abstract}

Index terms: Fruit growth; State of ripeness; Fruit quality; Plinia culiflora; Antocyanins

\section{INTRODUCTION}

The jabuticaba tree (Plinia spp. and Myrciaria spp.) stands out amongst the native species of importance in Brazil, being found in an extensive range of the country, from the State of Pará in the north to the State of Rio Grande do Sul in the south. The best known species is Plinia cauliflora (Mart.) Kausel (jabuticaba Sabará), which is intensely planted, showing medium growth but being highly productive. The fruit is highly appreciated, small (com diâmetro variando de 2 a $3 \mathrm{~mm}$ ) with a thin, sweet and almost black, epicarp, very tasty and showing early ripening (Gomes, 1983).

'Pingo de Mel'stands out amongst the existing varieties, and is widely planted in the region of Goiás, Brazil. It usually produces fruit once a year during a period of about 3 months. However, the jabuticaba fruit is highly perishable and should be consumed within 3 days after harvest, because due to short shelf life its commercial distribution, merchandizing and retail are difficult to achieve.

Despite its great sensory and nutritional potential, there are no studies concerning the physiological development of jabuticaba fruit, which is important for establishing the ideal point to harvest and to apply technology to retard or reduce the physiological activity after harvest. The vital cycle of a fruit can be divided into the following developmental phases: pre-ripening, ripening and senescence, covering different physiological and biochemical processes as from the formation of the organ to its death (Chitarra and Chitarra, 2005).

The evaluation of the developmental pattern of a fruit as from the flowering stage helps in establishing the ripeness indexes. Knowledge of the developmental phases is essential to aid in the determination of culturing practices, principally with respect to the most adequate ripeness

\footnotetext{
*Corresponding author:

Aricléia de Moraes Catarino, Post-Graduation Program in Agriculture in the Humid Tropics, National Research Institute of the Amazon, Manaus, AM, Brazil. E-mail: amoraescatarino@gmail.com
} 
state for commercial harvesting (Coombe, 1976; Esposti et al., 2008). Thus the objective of the present work was to characterize the jabuticaba fruits var. 'Pingo de Mel' throughout their physiological development by way of physical and chemical analyses.

\section{MATERIAL AND METHODS}

The experiment was carried out in the months of September and October of 2014 on the Fazenda e Vinicola Jabuticabal, in Nova Fátima, district of Hidrolândia, State of Goiás (GO), Brazil, located at the geographical coordinates of $16^{\circ} 55^{\prime} 32.35^{\prime \prime} \mathrm{S}$ and $49^{\circ} 21^{\prime} 39.76^{\prime \prime}$ W. Seventy trees were selected at random, homogenous as to the size and age, and branches were marked at the time of anthesis, with different colored wool yarn. The first harvest occurred at ten days after the anthesis, at intervals of four days until 34 DAA (days after the anthesis), when the fruits reached maturity, characterized by the black-violet color of the bark and the beginning of fruit fall, totaling 7 collection points. About $300 \mathrm{~g}$ of the jabuticaba fruits var. Pingo de mel were collected in the morning at random, among the 70 previously selected trees, and transported to the laboratory. Samples were collected 10, 14, 18, 22, 26, 30 and $34 \mathrm{DAA}$, being collected $300 \mathrm{~g}$ of the fruit each stage of development.

The jabuticaba fruits var. 'Pingo de Mel' were harvested in the morning and transported to the laboratory in plastic containers inside a polystyrene box containing ice. On arrival the fruits were selected and then washed under running water. They were evaluated with respect to their mass, longitudinal and cross-sectional diameters, color, respiration rate, firmness, $\mathrm{pH}$, titratable acidity in citric acid and total soluble solids. Part of the fruits was frozen in liquid nitrogen for the subsequent analysis of chlorophyll, anthocyanins, total and soluble pectin and starch.

\section{Analyses \\ Mass, longitudinal and cross-sectional diameters}

The mass was obtained by weighing on an analytical balance (Marte AY220) and the results are expressed in grams $(\mathrm{g})$. The longitudinal and cross-sectional diameters were measured with the aid of a digital caliper (Starfer, Digital Vernier Caliper IVEO-150mm), measuring the cross-sectional (horizontal) diameter and the longitudinal (vertical) diameter. The results were expressed in millimeters $(\mathrm{mm})$. For both mass and the diameters, 60 readings were taken from different fruits on the different analysis days.

\section{Respiratory rate}

The respiratory rate was determined by placing approximately $5 \mathrm{~g}$ of whole fruits in each of 6 glass jars to obtain the correct number of repetitions, and leaving for approximately $1 \mathrm{~h}$ at $25 \pm 2^{\circ} \mathrm{C}$ (room temperature). Aliquots of the atmosphere were then removed with the aid of a gas analyzer (Illinois instruments model 6600 Headspace Oxygen/Carbon dioxide analyzer). The results, expressed in $\% \mathrm{CO}_{2}$, were converted into $\mathrm{mL} \mathrm{CO}_{2} \cdot \mathrm{kg}_{\text {fruit }}{ }^{-1} \mathrm{~h}^{-1}$, taking the volume of the jar, the mass and volume of the fruits in each jar and the time the jar remained closed, into consideration.

\section{Color}

The color was determined by reading the three parameters defined by the CIEL system - L*, $\mathrm{a}^{*}$ and $\mathrm{b}^{*}$ - using a Hunterlab, ColorQuest II colorimeter. L* defined the luminosity $\left(\mathrm{L}^{*}=0=\right.$ black and $\mathrm{L}^{*}=100=$ white $)$ and $\mathrm{a}^{*}$ and $\mathrm{b}^{*}$ defined the chromaticity $\left(+\mathrm{a}^{*}=\right.$ red and $-\mathrm{a}^{*}=$ green, $+\mathrm{b}^{*}=$ yellow and $-\mathrm{b}^{*}=$ blue $)$. Once again sixty readings were taken using different fruits on the different days of analysis.

\section{Chlorophyll}

Chlorophyll was determined in $1 \mathrm{~g}$ of fresh skin, homogenized in $10 \mathrm{~mL}$ of water using a tissue homogenizer. The extract was transferred to a $50 \mathrm{~mL}$ volumetric flask and the volume completed with acetone. After a rest period in the dark ( 15 hours), the mixture was filtered and the absorbance was read at $652 \mathrm{~nm}$, expressing the results in mg.100 g-1 of fresh skin. This was calculated using the equation adopted by Engel and Poggiani (1991), carrying out 4 repetitions with 3 readings each, with a total of 12 readings, for each point. The chlorophyll content was only calculated up to $26 \mathrm{DAF}$, after which the fruit was no longer green.

\section{Anthocyanins}

The total anthocyanin content was estimated spectrophotometrically using the method of Lees and Francis (1972) with the adaptations made by Barcia et al. (2012). To extract the anthocyanins, $25 \mathrm{~mL}$ of an ethanol: 1.5 $\mathrm{M} \mathrm{HCl}(85: 15)$ solution were added to $1 \mathrm{~g}$ of whole fruit and incubated for $1 \mathrm{~h}$ at room temperature. The absorbance was then read at a wavelength of $535 \mathrm{~nm}$ in a spectrophotometer (Biospectro SP-220). The total anthocyanins were quantified based on the molar extinction coefficient of cyanidin-3-glycoside (Equation 1), being the main anthocyanin present in the fruits (Lima, 2009). The results were expressed in milligrams of cyanidin-3glycoside per 100 grams of sample.

Abs $=\in$.C.1

(Equation 1)

Where, Abs is the absorbance value read, $\in$ is the molar absorbance coefficient, $\mathrm{C}$ is the concentration mol. $\mathrm{L}^{-1}$ and 1 is the optical path in $\mathrm{cm}$. Four repetitions were made with 3 readings of each, giving a total of 12 readings, em cada ponto analisado. 


\section{Firmness}

Firmness was determined with the aid of a texturometer (Texture Analyzer, TA-XT Plus, Surrey, England) with the $\mathrm{P} / 2$ probe to analyze the penetration force. The previously determined values for the pre-test, test and post-test speeds were, respectively, $2 \mathrm{~mm} \mathrm{~s}^{-1}, 2 \mathrm{~mm} \mathrm{~s}^{-1}$ and $10 \mathrm{~mm} \mathrm{~s}^{-1}$, at a penetration distance of $6 \mathrm{~mm}$, with 10 repetitions, em cada ponto analisado. Firmness was expressed in Newton (N).

\section{Total and soluble pectin}

The total and soluble pectins were extracted following the technique described by McCready and McComb (1952) and determined colorimetrically by way of the carbazol reaction according to the technique modified by Bitter and Muir (1962). Four repetitions were done with 3 readings of each, giving a total number of readings of 12 , em cada ponto analisado. The total and soluble pectins were expressed in mg galacturonic acid $100 \mathrm{~g}^{-1}$ of fruit.

\section{Starch}

After extraction and chemical hydrolysis, the starch content was determined using the Somoygi method as adapted by Nelson (1944) and the results were expressed in mg starch $100 \mathrm{~g}^{-1}$ of fruit. Once again four repetitions were done with 3 readings of each giving a total number of readings of 12, em cada ponto analisado.

\section{Titratable acidity in citric acid and $\mathrm{pH}$ value}

The $\mathrm{pH}$ value was determined directly using a digital $\mathrm{pH}$ meter (Tecnal, TEC 3P-MP). The apparatus was calibrated using $\mathrm{pH} 4.0$ and $\mathrm{pH} 7.0$ standard buffer solutions, followed by the direct reading of the $\mathrm{pH}$ by immersion of the electrode in a beaker containing the sample macerated in an aqueous solution according to the methodology proposed by AOAC (2010). The titratable acidity in citric acid was determined by titration with a $0.01 \mathrm{~N}$ sodium hydroxide $(\mathrm{NaOH})$ solution using 1\% phenolphthalein as the indicator according to AOAC (2010). Once again four repetitions were done with 3 readings of each giving a total number of readings of 12 , em cada ponto analisado.

\section{Total soluble solids}

The total soluble solids content was determined by reading the degrees Brix of the sample at $20^{\circ} \mathrm{C}$ using a portable digital refractometer (Reichert, AR 200), according to the method proposed by AOAC (2010). Once again four repetitions were done with 3 readings of each giving a total number of readings of 12 , em cada ponto analisado.

\section{Statistical analyses}

The analyses was carried out using a completely randomized design (CRD) composed of seven maturation stages and three replicates, each replicate consisting of 60 fruits. The variables evaluated were subjected to a polynomial regression analysis as a function of the harvesting dates. The computer software SISVAR was used to fit the regression models by way of an $\mathrm{F}$ test at the $5 \%$ probability level, to measure the significance of the proposed model.

\section{RESULTS AND DISCUSSION}

The developmental stage of the jabuticaba fruits was 34 days, from flowering to the point of harvest, a period represented by growth, maturation and ripening of the fruits. According to Donadio (2000), the jabuticaba fruit ripens about 3 weeks after flowering, but this period can vary according to species, climate, soil and temperature, amongst other factors, and in the case of the jabuticaba var. 'Pingo de Mel', the developmental cycle was slightly longer.

During the 34 days ot the fruits' development, significant variation $(\mathrm{p} \leq 0.05)$ was observed in the longitudinal and cross-sectional diameters and in the mass (Fig. 1a, 1b and 1c). Note that the jabuticaba fruits grew rapidly in the first developmental stages, up to approximately 18 days after flowering (DAF), followed by slow growth up to $30 \mathrm{DAF}$, thus presenting a simple sigmoidal growth curve. A reduction in the longitudinal and cross-sectional diameters and in the mass was observed after 34 DAF. Neves et al. (2015) observed the same behavior for the physiological development of camu-camu, and according to these authors, the reduction in diameter and mass of the fruits at the end of development was due to transpiration of the fruits (loss of turgor). It can also be seen that the increase in the longitudinal and cross-sectional diameters occurred together, giving the characteristic round shape of the fruit (Fig. 1a and 1b).

The primary growth of the fruits was principally due to an increase in cell volume (Hulme, 1970), the period of growth being characterized by the maximum cell activity, increase in volume, intense green pigmentation and physiological immaturity (Ryall and Lipton, 1983). In addition, the gradual increase in weight during development occurred due to the accumulation of larger amounts of photoassimilated compounds, sugars and other carbohydrates (Carvalho and Nakagawa, 2000).

A significant $(\mathrm{p} \leq 0.05)$ reduction of the respiratory rate of the jabuticaba was observed during development of the fruits (Fig. 1d), presenting initial and final values of $1360.29 \mathrm{~mL}$ of $\mathrm{CO}_{2} \mathrm{~kg}$ fruit ${ }^{-1} \mathrm{~h}^{-1}$ and $184.62 \mathrm{~mL}$ of $\mathrm{CO}_{2} \mathrm{~kg}$ fruit $^{-1} \mathrm{~h}^{-1}$, respectively. Note that a greater amount of $\mathrm{CO}_{2}$ was produced during the first evaluation period (10 DAF), due to a high metabolic rate associated with the initial fruit development (Payasi and Sanwal, 2010). However an accentuated reduction was observed up to $14 \mathrm{DAF}$ and 


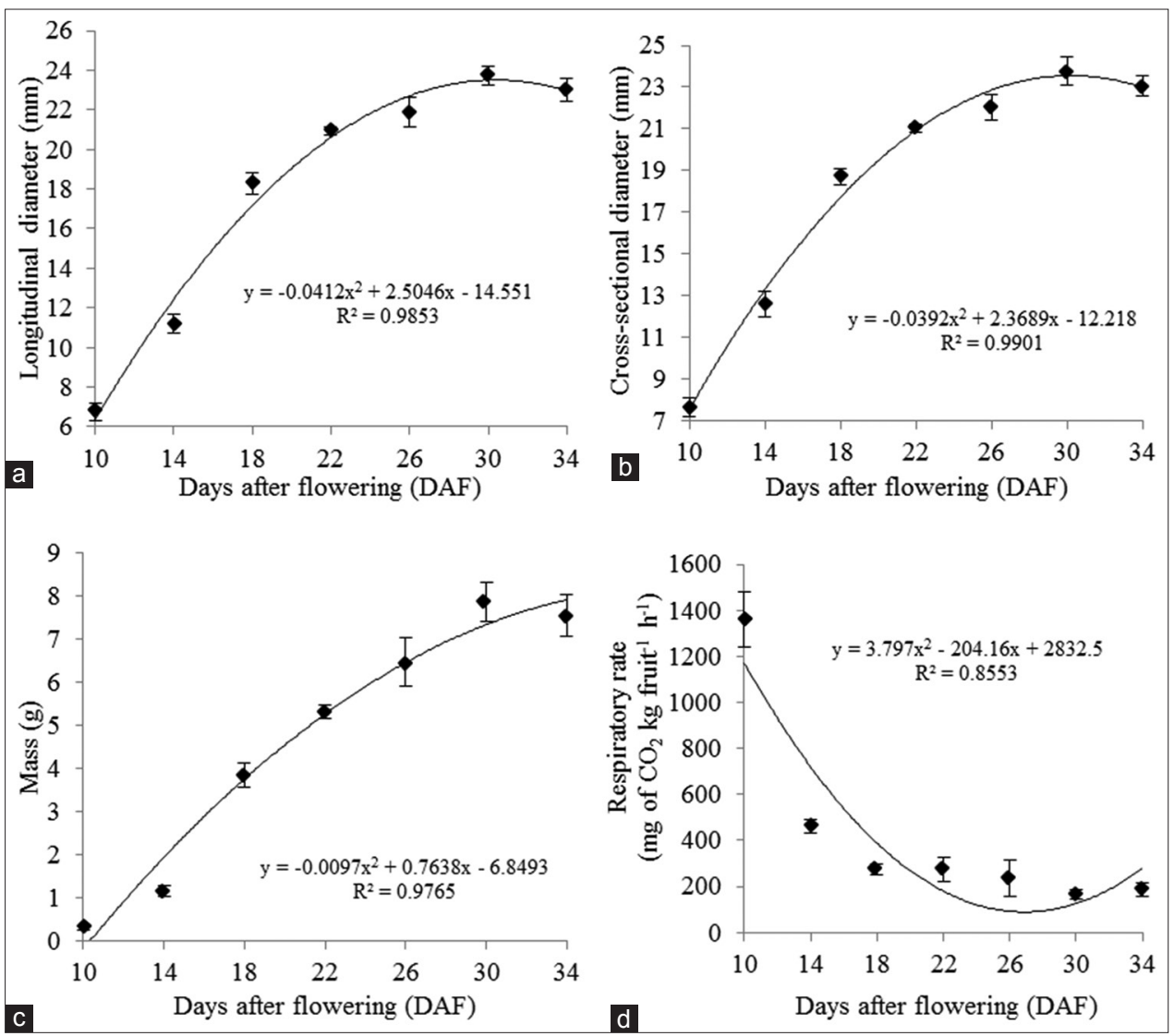

Fig 1. Mean values and standard deviation of the longitudinal (a) and cross-sectional (b) diameters, mass (c) and respiratory rate (d) during the development of jabuticaba fruit var. 'Pingo de Mel'.

as from $30 \mathrm{DAF}$ there was a tendency for stabilization. This is similar to that described by Taiz and Zieger (2006), who reported that when a vegetable tissue ripened, its respiratory rate remained more or less constant or slowly decreased as the tissue ages and finally senesced.

Fig. 2a shows that the soluble pectin contents increased during ripening of the jabuticaba fruits, being more accentuated up to $30 \mathrm{DAF}$. Araujo et al. (2010), on evaluating the soluble pectin content in the skin and pulp of jabuticaba fruits in the region of Minas Gerais, also observed a tendency to increase, corroborating the results of the present study. According to Lima and Durigan (2002), this increase in soluble pectin contents during fruit ripening occurs as a consequence of the pectic substances being degraded to soluble galacturonic acid, and in addition, the var. 'Pingo de Mel' shows different characteristics from the more commonly grown jabuticaba varieties.

According to Prassana et al. (2007), during the physiological development of fruits, the general tendency is for a reduction in the total pectin content to occur, no entanto no presente trabalho, como observado na Fig. 2b, o comportamento foi diferente, com elavação dos teores, com posterior queda. In counterpart, the firmness (Fig. 2c) showed a significant reduction $(\mathrm{p} \leq 0.05)$ throughout the developmental process of the fruits, this being more accentuated up to $26 \mathrm{DAF}$. This opposing behavior between soluble pectin and firmness occurred because, according to Silva et al. (2009), the fall in firmness can be a result of pectin depolymerization in the cell wall, which culminates in dissolution of the pectins during ripening by the action of hydrolytic enzymes.

The starch contents increased up to $26 \mathrm{DAF}$, followed by a rapid fall up to $34 \mathrm{DAF}$ (Fig. 2d). Similar behavior was observed by Wongmetha et al. (2015) on evaluating mangoes cv. Jinhwang. Climacteric fruits, such as bananas and kiwi, also contain large amounts of starch, which are degraded during ripening, resulting in significant amounts of sucrose in the ripe fruit (Cordenunsi and Lajolo, 1995; Redgwell and Harker, 1995). This behavior was explained by Evangelista (1999), who affirmed that starch was accumulated in the fruit during development and was subsequently degraded rapidly during ripening. This same author also found that the decrease was evident in the chloroplasts, where the starch granules reduced in size and practically disappeared in the ripe fruits. This decrease occurred because, during ripening, the starch was catabolized to glucose and fructose, which were used as 


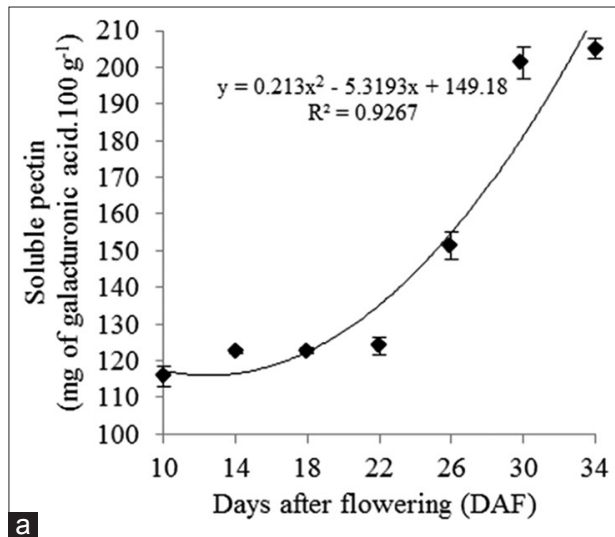

a
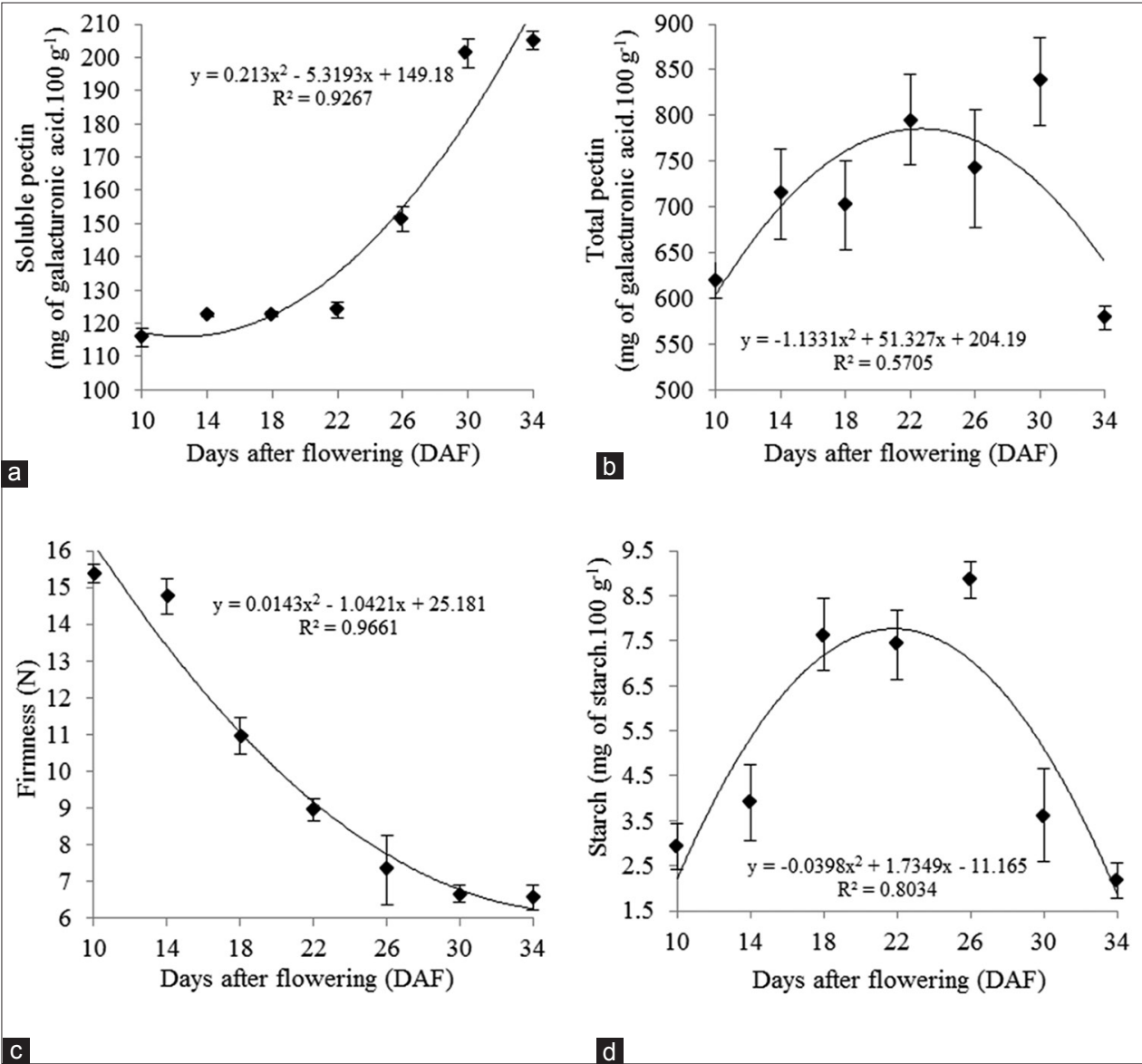

Fig 2. Mean values and standard deviations for soluble pectin (a), total pectin (b), firmness (c) and starch (d) during the development of jabuticaba fruits var. 'Pingo de Mel'.

respiratory substrates or converted into other metabolites (Paliyath and Murr, 2008). As in many other species, the starch degradation probably contributed to the increase in soluble solids content. As from $22 \mathrm{DAF}$ there was a sharp increase in soluble solids content, whilst the starch content started to decrease.

The $\mathrm{pH}$ values showed a reduction up to $18 \mathrm{DAF}$, followed by an increase up to the complete ripening of the fruits (Fig. 3a). Even with these variations, the $\mathrm{pH}$ values of the jabuticaba fruits were within the range expected for fruits, that is, from 3.0 to 4.5 (Gava et al., 2007).

Initially the titratable acidity increased until reaching a

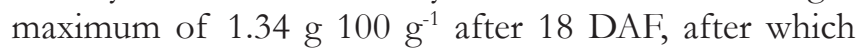
it descreased during the rest of development (Fig. 3b). In general, the titratable acidity of fruits decreases with the advance of ripening due to the respiration process, and the conversion of acids into sugars. On evaluating the harvesting time of camu-camu, Neves et al. (2015) observed that this fruit showed the opposite behavior to that of jabuticaba, with a reduction in the titratable acidity values up to $88 \mathrm{DAF}$, followed by an increase up to 102
DAF. Thus the acidity of fruits can decrease or increase depending on a species, since the organic acids are used in respiration to produce ATP, resulting in a decrease in the acidity. The respiration process itself can also produce organic acids, which can accumulate in the fruit, resulting in a slight increase in acidity (Pimentel et al., 2010).

With respect to the total soluble solids content, this varied little during development (from $13.333^{\circ}$ Brix to 13.346 ${ }^{\circ}$ Brix), although the variation was significant $(\mathrm{p} \leq 0.05)$ (Fig. 3c). It can be seen that the total soluble solids content increased up to $30 \mathrm{DAF}$. The soluble solids content in fruits is influenced by the state of their maturation at the time of harvest. In general, this value increases during ripening due to biosynthesis or degradation of polysaccharides (Chitarra and Chitarra, 2005).

The soluble solids to titratable acidity ratio decreased up to 18 DAF, followed by an increase up to the final developmental period of the fruit under evaluation. This ratio is an important qualitative attribute, since it indicates the relative contributions of the compounds responsible for sweetness and acidity, and hence provides an indication of the flavor 


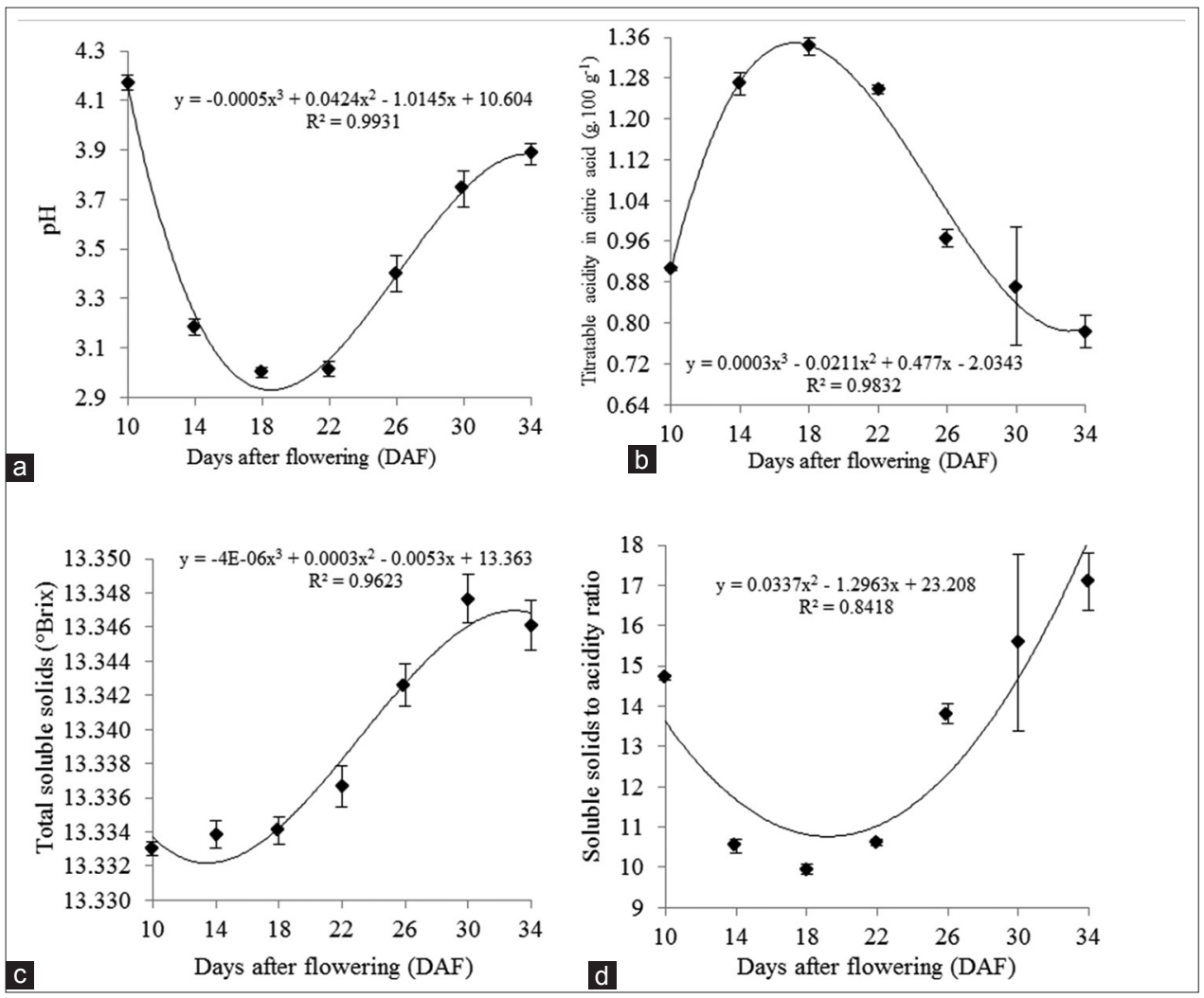

Fig 3. Mean values and standard deviations for $\mathrm{pH}$ (a), titratable acidity in citric acid (b), total soluble solids (c) and soluble solids to acidity ratio (d) during the development of the jabuticaba fruits var. 'Pingo de Mel'.

of the fruit (Prassana et al., 2007). In addition, this ratio is considered as a marker of the maturation phase of the fruit, capable of predicting the sweetness (Neves et al., 2015).

The luminosity $\left(\mathrm{L}^{*}\right)$ is a coordinate of the CIELAB color space which can vary from 0 to 100 , that is, from black to white (Lawless and Heymann, 2010). Thus it can be seen that the jabuticaba fruits became progressively darker with development (Fig. 4c), showing a tendency to 0, which is to be expected since the ripe jabuticaba fruits are very dark in color, almost black.

With respect to the color of jabuticaba, the changes were consistent with the results obtained in the analysis of the pigments, chlorophylls and anthocyanins (Fig. 5). The parameter $\mathrm{a}^{*}$ (chromaticity coordinate) of the jabuticaba skin (Fig. 4a) showed an initial value of -8.36 and final value of 0.51 , characterizing the process of the loss of the green color, a fact explained by the degradation of chlorophyll, which is a natural process in the ripening of fruits. The analysis of the anthocyanins, presented a result contrary to that of chlorophyll, increasing during ripening. The values for $\mathrm{b}^{*}$ (chromaticity coordinate) (Fig. 4b) varied from 29.48 to -1.55 during development of the fruit, presenting a tendency to blue coloration at the end of the ripening process.
As can be seen in Fig. 5 ( $a$ and b), with the degradation of the chlorophyll during ripening, the anthocyanins, previously present in the tissues), become visible, or were synthesized throughout the ripening process. The synthesis of flavonoid pigments also occurr, with coloration varying between blue, red and purple (Chitarra and Chitarra, 2005). The change in color is one of the most important criteria, together with appearance, used by the consumer to judge the degree of maturity and quality of the fruits, since the visual impact caused by the color is one of the factors that most influences consumer preference (Oliveira et al., 2003).

\section{CONCLUSIONS}

The developmental stage of the jabuticaba fruits var. 'Pingo de Mel' was 34 days, from anthesis to ripening fruit. During this period the fruits showed typical non-climacteric behavior and no increase in respiratory rate at any stage of the development. During the maturation and ripening there was an increase of parameters such as fruit diameters, masses, soluble pectins' content, $\mathrm{pH}$, soluble solids, ratio (relação entre os sólidos solúveis e a acidez titulável) and anthocyanins. However, the longitudinal and transverse diameters, bulk, solid soluble and anthocyanins showed tendency to decrease to $34 \mathrm{DAF}$, so the most suitable period 


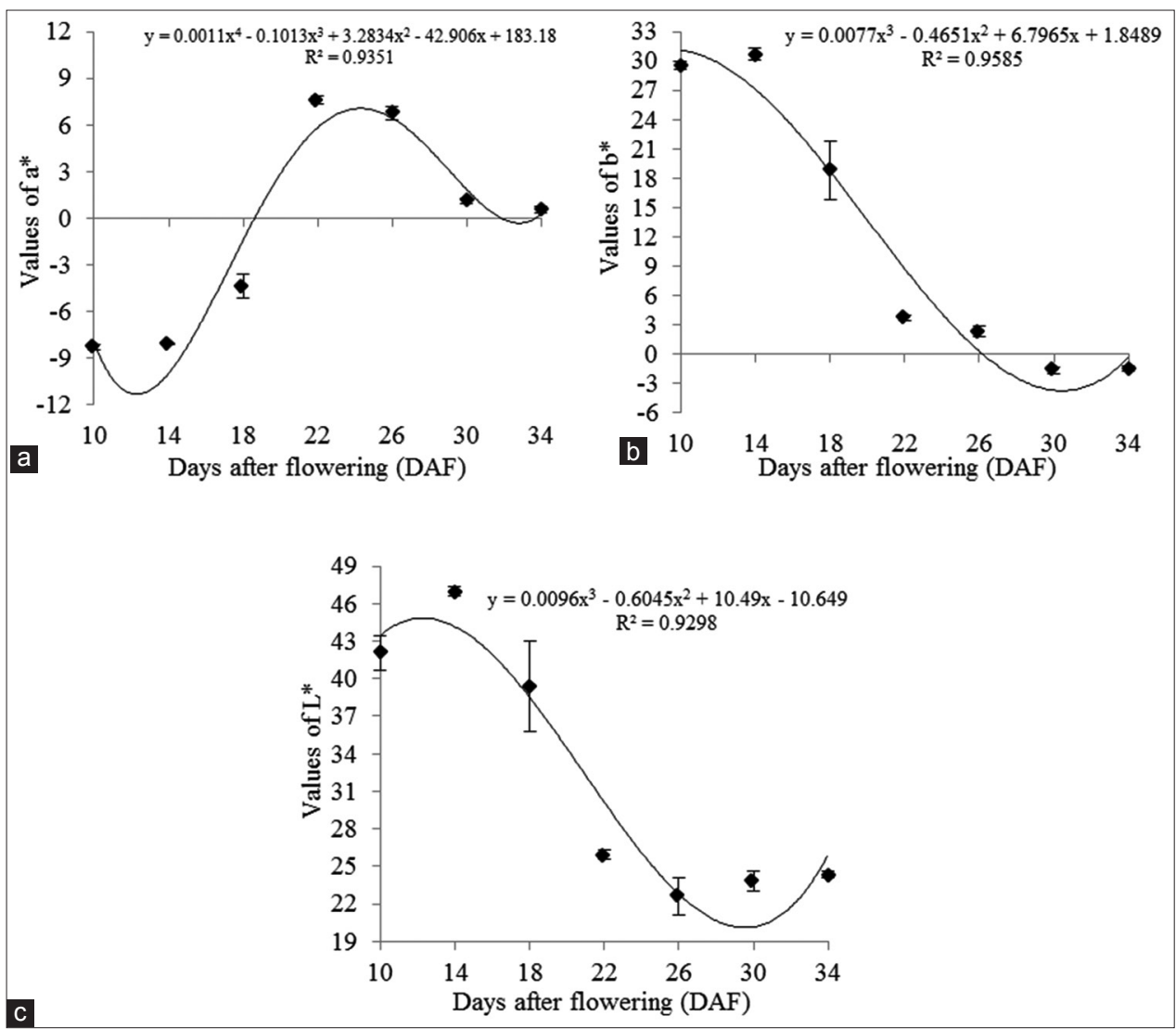

Fig 4. Mean values and standard deviations for $a^{*}(a), b^{*}(b)$ and $L^{*}(c)$ during the development of the jabuticaba fruits var. 'Pingo de Mel'.

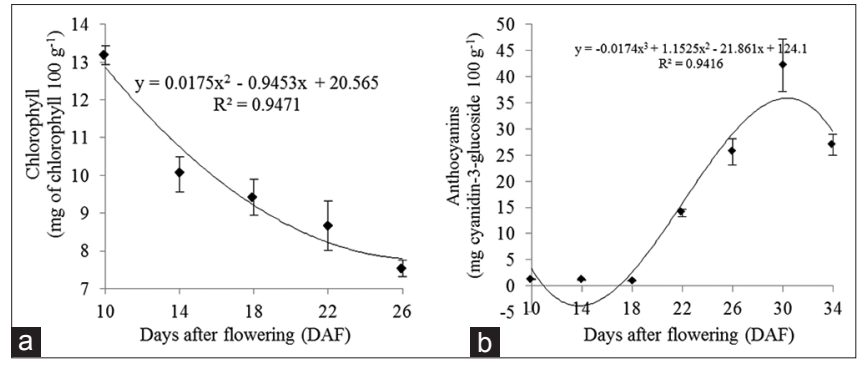

Fig 5. Mean values and standard deviations for chlorophyll and anthocyanins during the development of jabuticaba fruits var. 'Pingo de Mel'.

for harvesting the fruits of jabuticaba var. 'Pingo de Mel' would be 30 days after anthesis.

\section{ACKNOWLEDGEMENTS}

The authors are grateful to FAPEG (Research Foundation of the State of Goías, Brazil) for the concession of a scholarship to Lismaíra Gonçalves Caixeta Garcia and to the Fazenda e Vinicola Jabuticabal for donating the fruits used in the research.

\section{AUTHORS' CONTRIBUTIONS}

This experiment is an interdisciplinary one developed under field conditions with fruit analysis in laboratory. This
Manuscript is part of the Ph.D. Thesis (Plant Production) of Lismaíra Gonçalves Caixeta Garcia advised by Prof. Dr. Flávio Alves da Silva, Prof. Dr. Eduardo Valerio de Barros Vilas Boas, Prof. Dr. Eduardo Ramirez Asquieri and Profa. Dra. Clarissa Damiani. Thus, all authors accompanied all practices of the research. Monik Marielly Moreira da Silva acted on field data gathering, fruit analysis in laboratory.

\section{REFERENCES}

AOAC. 2010. Official Methods of Analysis. $18^{\text {th }}$ ed., Association of Official Analytical Chemists, Gaithersburg, US.

Araujo, F. M. M. C., A. V. Machado, H. C. Lima and A. B. Chitarra. 2010. Physical and chemical changes of the fruit of jabuticabeira (Myrciaria jabuticaba Berg cv. Sabara) during development. Rev. Verde. 5: 109-116.

Barcia, M. T., P. B. Pertuzatti, A. C. Jacques, H. T. Godoy and R. Zambiazi. 2012. Bioactive compounds, antioxidant activity and percent composition of jambolão fruits (Syzygium cumini). Nat. Prod. J. 2: 129-138.

Bitter, T. and H. M. Muir. 1962. A modified uronic acid carbazole reaction. Anal. Biochem. 4: 330-334.

Carvalho, N. M. and J. Nakagawa. 2000. Sementes: Ciência, Tecnologia e Produção. $4^{\text {th }}$ ed., FUNEP, Jaboticabal, SP.

Chitarra, M. I. F. and A. B. Chitarra. 2005. Pós-colheita de Frutas e Hortaliças: Fisiologia e Manuseio. $2^{\text {th }}$ ed., UFLA, Lavras, MG.

Coombe, B. G. 1976. The development of fleshy fruits. Annu. Rev. 
Plant. Physiol. 27: 507-528.

Cordenunsi, B. R. and F. M. Lajolo. 1995. Starch breakdown during banana ripening: Sucrose synthase and sucrose phosphate synthase. J. Agric. Food Chem. 2: 347-351.

Donadio, L. C. 2000. Jabuticaba (Myrciaria jaboticaba (Vell) Berg). FUNEP, Jaboticabal, SP.

Engel, V. L. and F. Poggiani. 1991. Estudo da concentração de clorofila nas folhas e seu espectro de absorção de luz em função do sombreamento em mudas de quatro espécies florestais nativas. Rev. Bras. Fisiol. Veg. 3: 39-45.

Esposti, M. D., D. L. Siqueira and P. R. Cecon. 2008. Crescimento de frutos da tangerineira 'Poncã' (Citrus reticulate Blanco). Rev. Bras. Frutic. 30: 657-661.

Evangelista, R. M. 1999. Qualidade de Mangas 'Tommy Atkins' Armazenadas Sob Refrigeração e Tratadas Com Cloreto de Cálcio Pré-colheita. 1999. 129f. Ph.D. Thesis, Federal University of Lavras, Lavras.

Gava, A. J., C. A. B. Silva and J. R. G. Frias. 2007. Tecnologia de Alimentos: Princípios e Aplicações. Nobel, São Paulo, SP.

Gomes, R. P. 1983. Fruticultura Brasileira, $9^{\text {th }}$ ed., Nobel, São Paulo, SP.

Hulme, A. C. 1970. The Biochemistry of Fruits and their Products, Academic Press, London.

Lawless, H. T. and H. Heymann. 2010. Sensory Evaluation of Food: Principles and Practices, Springer Science \& Business Media, Maryland.

Lees, D. H. and F. J. Francis. 1972. Standardization of pigment analyses in cranberries. Hort Sci. 7: 83-84.

Lima, A. J. B. 2009. Caracterização e Atividade Antioxidante da Jabuticaba [Myrciaria cauliflora (Mart.) O. Berg]. 2009. $159 f$. Ph.D. Thesis, Federal University of Lavras, Lavras.

Lima, M. A. and J. F. Durigan. 2002. Reguladores vegetais na conservação pós-colheita de goiabas 'Paluma'. Rev. Bras. Frutic. 24: 370-375.

McCready, P. M. and E. A. McComb. 1952. Extration and determination of total pectin material in fruits. Anal. Chem. 24: 1586-1588.
Nelson, N. A. 1944. A photometric adaptation of somogyi method for the determination of glucose. J. Biol. Chem. 153: 375-380.

Neves, L. C., V. X. Silva, E. A. Chagas, C. G. B. Lima, and S. R. Roberto. 2015. Determining the harvest time of camu-camu [Myrciaria dubia (H.B.K.) McVaugh] using measured pre-harvest atributes. Sci. Hortic. 186: 15-23.

Oliveira, A. L., M. A. Brunini, C. A. R. Salandini and F. R. Bazzo. 2003. Caracterização tecnológica de jabuticabas 'Sabará' provenientes de diferentes regiões de cultivo. Rev. Bras. Frutic. 25: 397-400.

Paliyath, G. and D. P. Murr. 2008. Biochemistry of fruits. In: Paliyath, G., D. P. Murr, A. K. Handa and S. Lurie (Eds.), Postharvest biology and technology of fruits, vegetables and flowers, WileyBlackwell, lowa, US, pp. 19-50.

Payasi, A. and G. G. 2010. Sanwal. Ripening of climacteric fruits and their control. J. Food Biochem. 34: 679-710.

Pimentel, R. M. A., F. N. Guimarães, V. M. Santos and Resende, J. C. F. 2010. Qualidade pós-colheita dos genótipos de banana PA4244 e prata-anã cultivados no norte de minas gerais. Rev. Bras. Frutic. 32: 407-412.

Prassana, V., T. N. Prabha and R. N. Tharanathan. 2007. Fruit ripening phenomena - An overview. Crit. Rev. Food Sci. Nutr. 47: 1-19.

Redgwell, R. J. and R. Harker. 1995. Softening of kiwifruits discs: Effect of inhibition of galactose loss from cell walls. Photochemistry. 39: 1319-1323.

Ryall, A. L. and W. Lipton. 1983. Handling, Transportation and Storage of Fruits and Vegetables, $2^{\text {th }}$ ed., AVI Puublishing, Westport.

Silva, E. P., E. V. B. Vilas Boas, L. J. Rodrigues and H. H. Siqueira. 2009. Physical, chemical and physiological characterization of gabiroba fruit (Campomanesia pubescens) during its development. Food Sci. Technol. 29: 803-809.

Taiz, L. and E. Zeiger. 2006. Fisiologia Vegetal, $3^{\text {th }}$ ed., Artemed, Porto Alegre, RS.

Wongmetha, O., L. S. Ke and Y. S. Liang. 2015. The changes in physical, bio-chemical, physiological characteristics and enzyme activities of mango cv. Jinhwang during fruit growth and development. NJAS. 72: 7-12. 